\title{
THE DISTRIBUTION AND CHROMATOGRAPHIC CHARACTERIZATION OF PHI (PEPTIDE HISTIDINE ISOLEUCINE AMIDE)-27-LIKE PEPTIDES IN RAT AND PORCINE BRAIN ${ }^{1}$
}

\author{
MARGERY C. BEINFELD, ${ }^{2}$ DIANA M. KORCHAK, BRYAN L. ROTH,* AND T. L. O’DONOHUE $\ddagger$ \\ Department of Pharmacology, St. Louis University, St. Louis, Missouri 63104; * Department of Psychiatry, Naval Medical \\ Hospital, Bethesda, Maryland 20814 and Laboratory of Preclinical Pharmacology, National Institute of Mental Health, \\ Washington, D.C. 20032; and $\ddagger$ Experimental Therapeutics Branch, National Institute of Neurological and Communicative \\ Disorders and Stroke, National Institutes of Health, Bethesda, Maryland 20205
}

Received October 28, 1983; Revised February 27, 1984; Accepted April 12, 1984

\begin{abstract}
This study was initiated to characterize PHI (peptide histidine isoleucine amide)-27-like peptides (PLPs) in rat and porcine brain in comparison with other members of the vasoactive intestinal polypeptide (VIP) family and to investigate their distribution by radioimmunoassay.

The peptidic nature of the rat brain PLP was indicated by its trypsin sensitivity. On Sephadex chromatography rat brain PLP has the same molecular weight as synthetic (porcine intestinal) PHI-27. High pressure liquid chromatographic separations revealed that PLP in rat and porcine brain extracts elutes as a single peak distinct from VIP or secretin. Porcine brain PLP elutes in the same position as synthetic PHI-27, whereas rat brain PLP immunoreactivity consistently separates from synthetic PHI-27. This suggests that porcine brain PLP is identical to synthetic PHI-27, in agreement with the reported sequence of Tatemoto et al. (Tatemoto, K., M. Carlquist, T. McDonald, and V. Mutt (1983) FEBS Lett. 153: 248-252), whereas PLP may have a different amino acid sequence (or may be post-translationally modified).

Using specific PHI and VIP radioimmunoassays, the distribution of PLP was found to parallel that of VIP in rat and porcine brain, being highest in cerebral cortex, amygdala, and hippocampus. PLP, like VIP, is abundant in rat retina and can be included in the growing list of retinal peptides. This highly correlated distribution of VIP and PLP may be explained by the recent discovery that they are derived from the same precursor (Itoh, N., K. Obata, N. Yanaihara, and H. Okamoto (1983) Nature 301: 547-519). In some brain regions, however, the distribution of the two peptides was less strongly correlated, which perhaps could be explained by differential local regulation of gene translation or peptide processing.

The closely correlated distribution of brain VIP and PLP and the known ability of PHI-27, like VIP, to activate adenylate cyclase (Jensen, R. T., K. Tatemoto, V. Mutt, G. Lemp, and J. Gardner (1982) Am. J. Physiol. 241: G498-G502; Watling, K. J., and J. E. Dowling (1983) J. Neurochem. 41: 1205-1213; Roth, B. L., M. C. Beinfeld, and A. C. Howlett (1984) J. Neurochem. 42: 1145-1152) and inhibit VIP binding (Jensen, R. T., K. Tatemoto, V. Mutt, G. Lemp, and J. Gardner (1982) Am. J. Physiol. 241: G498-G502; Robberecht, P., K. Tatemoto, P. Chatelain, M. Waelbroeck, M. Delhaye, G. Taton, P. DeNeff, J. Camus, J. C. Hause, and J. Christophe (1982) Regul. Pept. 4: 241-250) suggest that PLPs may play a role as endogenous modulators of VIP activity.
\end{abstract}

Peptide histidine isoleucine amide (PHI)-27 was isolated from porcine intestine (Tatemoto and Mutt, 1981) and the identical sequence was found in porcine brain (Tatemoto et al., 1983): This peptide has strong sequence homology with vasoactive intestinal peptide (VIP), secretin, glucagon, gastric inhibitory peptide, and newly discovered growth hormone-releasing hormone (GHRH). PHI-27 has VIP- and secretin-like

${ }^{1}$ This work was supported by National Institutes of Health Grants NS 18335 and NS 18667 and by a grant from the American Parkinson Disease Association. We wish to thank Ms. Maggie Klevorn for expert secretarial assistance.

${ }^{2}$ To whom correspondence should be addressed. activities in several tissues. It stimulates amylase secretion and elevates levels of cAMP in pancreatic acinar cells (Jensen et al., 1982), lung membranes (Robberecht et al., 1982), rat neuroblastoma cells (Roth et al., 1984), carp retinal pieces and isolated horizontal cells (Watling and Dowling, 1983), and intestinal epithelial cells, fat cells, and gastric glands (Bataille et al., 1980). Under some conditions PHI-27 is more potent than VIP in releasing prolactin from dispersed anterior pituitary cells and hemipituitaries of the rat (Werner et al., 1983). Other VIP-like actions of PHI-27 have recently been summarized (Christofides et al,, 1982a). PHI-27 can inhibit ${ }^{125}$ I-labeled VIP binding in these systems (although with lower affinity than VIP) and appears to activate adenylate cyclase via the VIP or secretin receptors in these tissues. 
A PHI-like peptide (PLP) has been detected in rat, human, guinea pig, and cat brain and peripheral tissues by radioimmunoassay (RIA) (Christofides et al., 1982a, b, 1983). However, detailed descriptions of PLP's distribution, chemical nature, chromatographic characteristics, and its relationship to other structurally related peptides in brain have not yet been reported. In preliminary reports, a striking similarity in the distribution of VIP and PLP was observed (Christofides et al., 1982a). Immunocytochemical staining of central and peripheral tissues indicated that VIP and PLP were often co-localized in the same neurons, although Hokfelt et al. (1982) found this not to be true for the paraventricular nucleus and the median eminence. This close association of VIP and PLP has led to the suggestion that PLP and VIP might originate from the same precursor peptide. The cloning of the mRNA for VIP from a human neuroblastoma cell line has revealed the presence of an amino acid sequence which codes for a peptide very similar to PHI (25 of 27 amino acids the same) (Itoh, et al., 1983). Whether the mRNA which codes for this PLP (called PHM-27) is the human equivalent of PHI or whether other mRNAs exit which code for PHI-27 in humans has not been determined.

This study was initiated to examine in greater detail the chemical composition and chromatographic characteristics of PLP, its relationship to VIP and other chemically related brain peptides, and its distribution in rat and porcine brain.

\section{Materials and Methods}

\section{PHI anliserum}

A specific antiserum against porcine $\mathrm{PHI}$ was obtained by immunizing male New Zealand White rabbits with synthetic PHI-27 (Penninsula Laboratories) conjugated to bovine serum albumin with glutaraldehyde. The conjugate was prepared by adding dropwise $3.5 \mathrm{ml}$ of a solution of freshly prepared $22 \mathrm{mM}$ glutaraldehyde to a mixture of 0.5 $\mathrm{mg}$ of PHI-27 dissolved in $0.5 \mathrm{ml}$ of phosphate buffer $(0.05 \mathrm{mM}, \mathrm{pH}$ 7.4 ) and $7.5 \mathrm{mg}$ of bovine serum albumin dissolved in $1.2 \mathrm{ml}$ of $0.38 \mathrm{M}$ borate buffer, $\mathrm{pH} 8.5$. The rabbits were injected at approximately 2week intervals with conjugate containing $50 \mu \mathrm{g}$ of PHI in Fruend's complete adjuvant and were bled periodically, 3 days after immunization. 'The bleed used in the study (bleed 5) was obtained about 6 months after the beginning of the immunizations.

\section{$P H I$ and VIP radioimmunoassays}

PHI and VIP were iodinated by the same procedure, and the labeled peptides were separated using a fibrous cellulose column (Christophe et al., 1976). The labeled peptides were stable for 3 to 4 weeks at $-20^{\circ} \mathrm{C}$. The PHI antiserum was used at a final dilution of 1:20,000 in a final assay volume of $0.5 \mathrm{ml}$ using phosphate-buffered saline (PBS; $10 \mathrm{mM}$ sodium phosphate, $\mathrm{pH} 7.4,0.15 \mathrm{M} \mathrm{NaCl}$ ) containing $0.1 \%$ ethylmercurithiosalicylate and $25 \mathrm{~mm}$ EDTA. The assay employed a non-equilibrium method in which antibody, buffer, and samples were incubated for $24 \mathrm{hr}$ at $4^{\circ} \mathrm{C}$, iodinated peptide ( 4000 to $\left.8000 \mathrm{cpm}\right)$ was added, and the assay was stopped 16 to $18 \mathrm{hr}$ later. Free and bound labeled peptide were separated by dextran-charcoal (5 gm of Decton-Dickinson RIAgrade Norit and $0.5 \mathrm{gm}$ of Becton-Dickinson RIA-grade dextran/liter of PBS), $1 \mathrm{ml} /$ tube, followed by centrifugation at $1,800 \times \mathrm{g}$ for $15 \mathrm{~min}$. The supernatant was decanted and counted for 1 min in a Beckman 8000 gamma counter interfaced with an Apple II+ computer. Results were calculated utilizing the National Instituies of Health RIA program of Rodbard and Munson (1980), which employs a nonlinear least squares approximation of the log-logit transformation. The National Institutes of Health RIA program as provided by Biomedical Computing Technology Information Center, Vanderbilt University, Nashville, TN.

The PHI assay can reliably detect 10 to $20 \mathrm{pg} /$ tube, with an $\mathrm{ED}_{50}$ to 50 to $100 \mathrm{pg} /$ tube. The antiserum cross-reacts weakly with secretin $(0.8 \%)$, glucagon $(0.05 \%)$, and PHM- $27(0.02 \%)$, but at $1 \mu \mathrm{g} /$ tube it displays no cross-reactivity with any of the other peptides in the VIPsecretin family or with other unrelated neuropeptides tested (see Fig. 1).

VIP RIA. VIP RIA was performed as previously described (Eiden et al., 1982), using a VIP antiserum, N2-12 (kindly provided by Dr. G.
Nilaver), with low cross-reactivity for PHI-27 (0.02\%). It was used at a final dilution of 1:60,000. The VIP assay can reliably detect 2.5 to 5 $\mathrm{pg} / \mathrm{tube}$, with an $\mathrm{ED}_{50}$ of 15 to $25 \mathrm{pg} / \mathrm{tube}$.

\section{Tissue dissection and extraction}

To determine the best extraction method for PLP from rat brain, several methods which work well for VIP were tested along with other methods which work well for other peptides. The results are shown in Table I.

The porcine brains were dissected at the slaughterhouse, frozen on dry ice, extracted in boiling water, and centrifuged at $10,000 \times g$ for 10 $\mathrm{min}$, and the pellets were re-extracted with $0.5 \mathrm{M}$ acetic acid. The two supernatants were combined, dried down, resuspended, and assayed for PLP and VIP.

For the gross dissection of rat brain, the rat brain was placed in a Plexiglas brain block and sliced with razor blades into 1-mm slices, placed on iced glass slides, and dissected free-hand into the areas described. The dissected areas were frozen on dry ice and stored at $-20^{\circ} \mathrm{C}$ until they were extracted by sonication in $0.1 \mathrm{~N} \mathrm{HCl}$. An aliquot was removed from each homogenate for Lowry protein determination (Lowry et al., 1951); the extracts then were clarified by centrifugation at $10,000 \times g$ for $10 \mathrm{~min}$. The $0.1 \mathrm{~N} \mathrm{HCl}$ extracts were neutralized with an equal volume of $0.1 \mathrm{~N} \mathrm{NaOH}$ prior to the VIP or PHI RIA. The micropunches were prepared by the method of Palkovits (1973) and were extracted as previously described (Beinfeld and Palkovits, 1982).

\section{Chromatography}

\section{Sephadex}

A 1.0-ml sample of $0.1 \mathrm{~N} \mathrm{HCl}$ extract of rat brain (equivalent to onetenth of a rat brain) was applied to a $1 \times 100 \mathrm{~cm}$ column of Sephadex G-50 (Superfine) previously equilibrated with $1 \%(\mathrm{v} / \mathrm{v})$ acetic acid. The elution of rat brain PLPs was compared with the elution of synthetic PHI, blue dextran (void volume marker), and $\mathrm{Na}^{125} \mathrm{I}$ (included volume marker). Two-milliliter fractions were collected, and aliquots were removed and dried prior to the RIA.

\section{$H P L C$}

Three chromatographic systems were used to compare the elution of porcine and rat brain VIP and PHI peptides. All employed a Varian 5000 equipped with an LDC Spectrometer III variable wavelength UV detector and were run at $1 \mathrm{ml} / \mathrm{min}$ with $1-\mathrm{ml}$ fractions collected.

A. C18-TEAP system. This system utilized octadecylsilane (C18) column from Alltech $(0.45 \times 25 \mathrm{~cm} ; 5-\mu \mathrm{m}$ particle size) run with a linear gradient, lasting $60 \mathrm{~min}$, from $20 \%$ to $60 \%$ acetonitrile in triethylamine/phosphoric acid, pH 3.25 .

B. C18-TFA system. This system used column run with a linear gradient, lasting $60 \mathrm{~min}$, of $20 \%$ to $80 \%$ buffer $\mathrm{B}$ (acetonitrile:water:trifluoracetic acid (TFA), 900:99:1, v/v/v, buffer A (water:TFA, 999:1, v/v).

C. Phenyl TFA system. This sytem utilized a Waters phenyl column $(25 \times 0.45 \mathrm{~cm})$ and the same buffer system as in system B, with a gradient from 20 to $60 \%$ buffer B, lasting $60 \mathrm{~min}$.

Fractions were dried in a Savant vacuum centrifuge and assayed for PHI and VIP. The elution of VIP and PHI immunoreactivity in rat and porcine brain was compared to the elution of synthetic (porcine) VIP and PHI-27 optical activity and immunoreactivity. Standards were run before and after the brain samples, with extensive washing and blank injections of water in between to ensure that no carryover of standards into sample occurred.

\section{Protease digestion of $\mathrm{PHI}$}

Trypsin (Sigma, type III, bovine pancreas, 11, $250 \mathrm{~N}$ - $\alpha$-benzoyl-Larginine ethyl ester units/mg of protein) was added at a final concentration of $5 \mathrm{mg} / \mathrm{ml}$ to $1 \mathrm{ng}$ of synthetic PHI or a volume of rat extract containing $1.4 \mathrm{ng}$ of PHI-like immunoreactivity, in a final volume of $1.6 \mathrm{ml}$ containing $13 \mathrm{~mm}$ sodium phosphate, $\mathrm{pH}$ 7.6. The samples were incubated at $37^{\circ} \mathrm{C}$, and aliquots were removed at 15,30 , and $45 \mathrm{~min}$, boiled for $10 \mathrm{~min}$, and assayed for PHI.

\section{Results}

Chemical composition of the PHI-like immunoreactive substance in rat brain. When either a rat brain extract or synthetic PHI-27 was treated with trypsin, the PLP immunoreactivity 


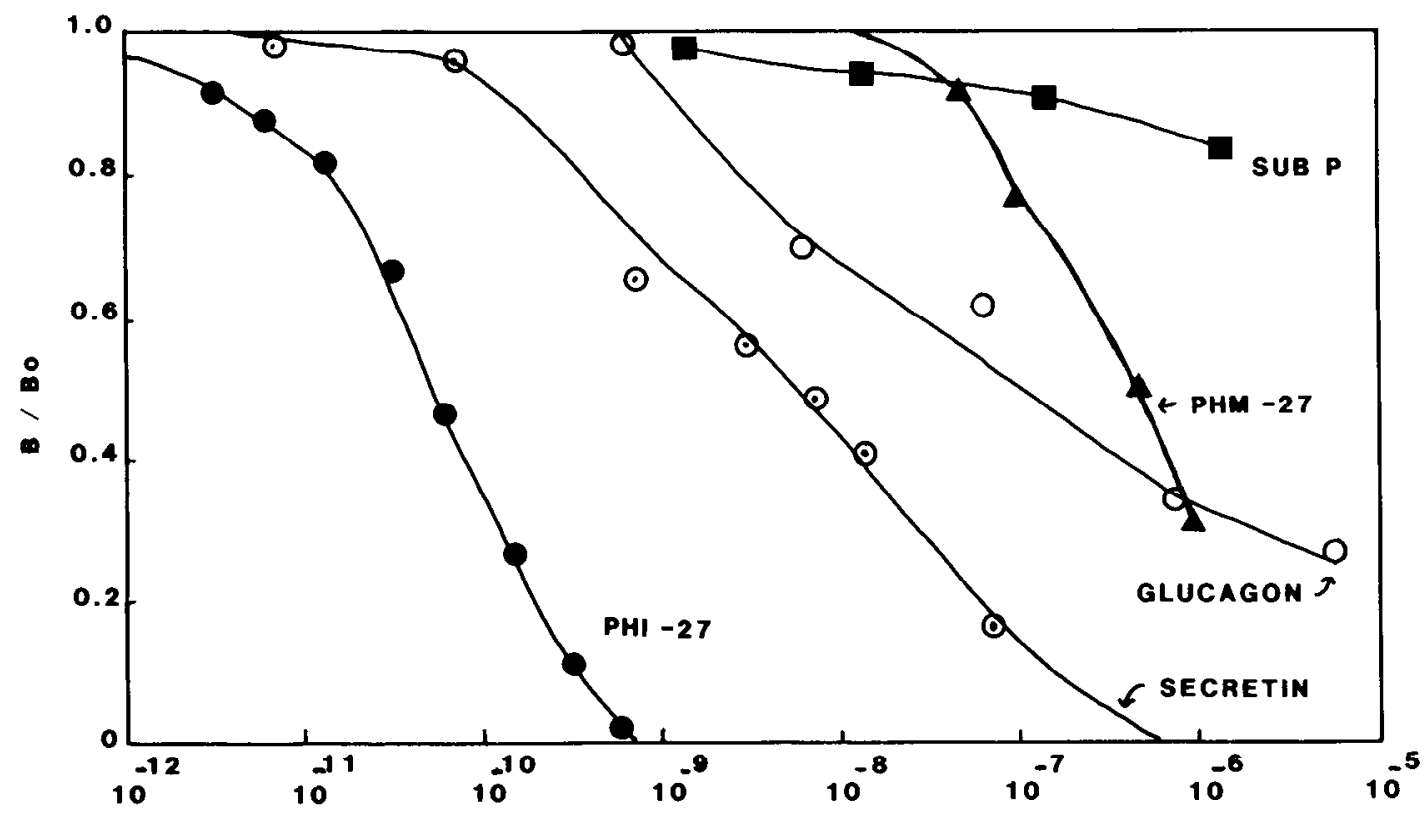

PEPTIDE CONCENTRATION (M)

Figure 1. Immunological characterization of the PHI antiserum (P3) used in this study. P3 cross-reacts weakly with secretin (0.8\%), glucagon $(0.05 \%)$, and PHM-27 $(0.02 \%)$ but displays no cross-reactivity with other structurally related peptides (VIP, gastric inhibitory peptide, motilin, and GHRH) or unrelated peptides (Leu-enkephalin, gastrin, or cholecystokinin-8) tested to $1 \mu \mathrm{g} / \mathrm{ml}$.

\section{TABLE I}

The effect of different extraction methods on the recovery of PHI-like immunoreactivity from rat brain

Rat brains were split sagittally into two equal pieces at the midline, frozen, weighed, and extracted individually by the different methods in groups of three, in a volume of $5.0 \mathrm{ml}$. All boiling steps were for 10 min. Homogenization was performed with a Tekmar Ultra-Turrax homogenizer. In method 3, the re-extraction was at room temperature. In method 5 , the tissue was homogenized in $75 \%$ acetone $/ 22 \%(4.5 \%$ $\mathrm{v} / \mathrm{v}$ ) acetic acid. In methods 4 and 5 , the extraction was done at room temperature.

\begin{tabular}{lc}
\hline \multicolumn{1}{c}{ Extraction Method } & PHI \\
\cline { 2 - 2 } $\begin{array}{l}n \mathrm{~g} / \mathrm{gm} \text { of } \\
\text { wet } w t .\end{array}$ \\
1. Boiling water & $60 \pm 0.3$ \\
2. Boiling 0.5 M acetic acid & $206 \pm 16$ \\
3. Boiling water, re-extract pellet with $0.5 \mathrm{M}$ & $101 \pm 16$ \\
acetic acid & \\
4. 0.1 N HCl & $249 \pm 36$ \\
5. Acid/acetone & $137 \pm 8$ \\
\hline
\end{tabular}

was completely eliminated in 15 min. This indicates that PLP in rat brain is a peptide and that, like synthetic PHI-27, which is cleaved by trypsin into five fragments (Tatemoto and Mutt, 1981), it has trypsin-sensitive basic residues in portions of the sequence where cleavage eliminates immunoreactivity.

Sephadex chromatography of rat brain extracts. A rat brain extract was applied to a Sephadex G-50 column and the elution of PLP was determined (see Fig. 2). The majority of the PHIlike material eluted in the same position as synthetic PHI, although additional peaks appear with a higher apparent molecular weight. These additional peaks could be either biosynthetic precursors to PLP, PLP aggregates, or other peptides with some degree of cross-reactivity with the PHI antiserum. Further experiments would be required to determine the identity of this immunoreactive material.

High pressure liquid chromatographic (HPLC) separation of $P L P$ from rat and porcine brain. Rat and porcine extracts were subjected to HPLC separations as described under "Materials and Methods." Three different systems were used, and since the data obtained on all of them were very similar, the data from only two systems are included. On all systems, rat and porcine brain PLP elutes as a single major peak separated from secretin and VIP. Porcine brain PLP co-elutes with synthetic PHI-27 as would be expected, whereas rat brain PLP elutes three to four fractions before synthetic PHI-27, indicating that it is less hydrophobic. VIP-like immunoreactivity in both porcine and rat brain co-elutes with synthetic VIP, in agreement with sequence data on VIP in these two species (Said and Mutt, 1970; Dimaline et al., 1983) (Fig. 3). There is an additional smaller peak of VIP immunoreactivity which elutes near secretin in rat and porcine brain. Since the VIP antiserum has no cross-reactivity with secretin when tested at $1 \mu \mathrm{g} /$ assay tube, it is unlikely that it is secretin. A minor peak of PLP also occurs in the same location in porcine brain but not in rat brain. Based on the secretin content of brain and the low crossreactivity of the PHI antiserum for secretin, it is unlikely that this peak is secretin. The nature of this peak is unknown, although it could be modified VIP or PHI peptide, or perhaps is yet another member of the VIP family. The observation that it is detected by both VIP and PHI antisera suggests the latter possibility. On a phenyl HPLC column rat PLP also elutes as a single major peak separated from VIP, PLP, and secretin (see Fig. 4).

Distribution of $P H I$ and VIP in rat and porcine brain. Based on the chromatographic characterization data, it is likely that rat PLP is different from PHI-27. Until the sequence of rat PLP is known and its degree of cross-reactivity with the PHI27 antiserum is determined, precise quantitation of PLP levels in rat brain cannot be performed. However, the PHI RIA can provide a good relative measure of the abundance of PLP peptides in different brain regions.

The distribution of PLP and VIP was determined by RIA in major regions of rat and procine brain and in microdissected regions of rat brain. The data for the major regions of rat brain are presented in Table II. The distribution of PLP clearly parallels that of VIP. Like VIP, the PLP concentration in some 


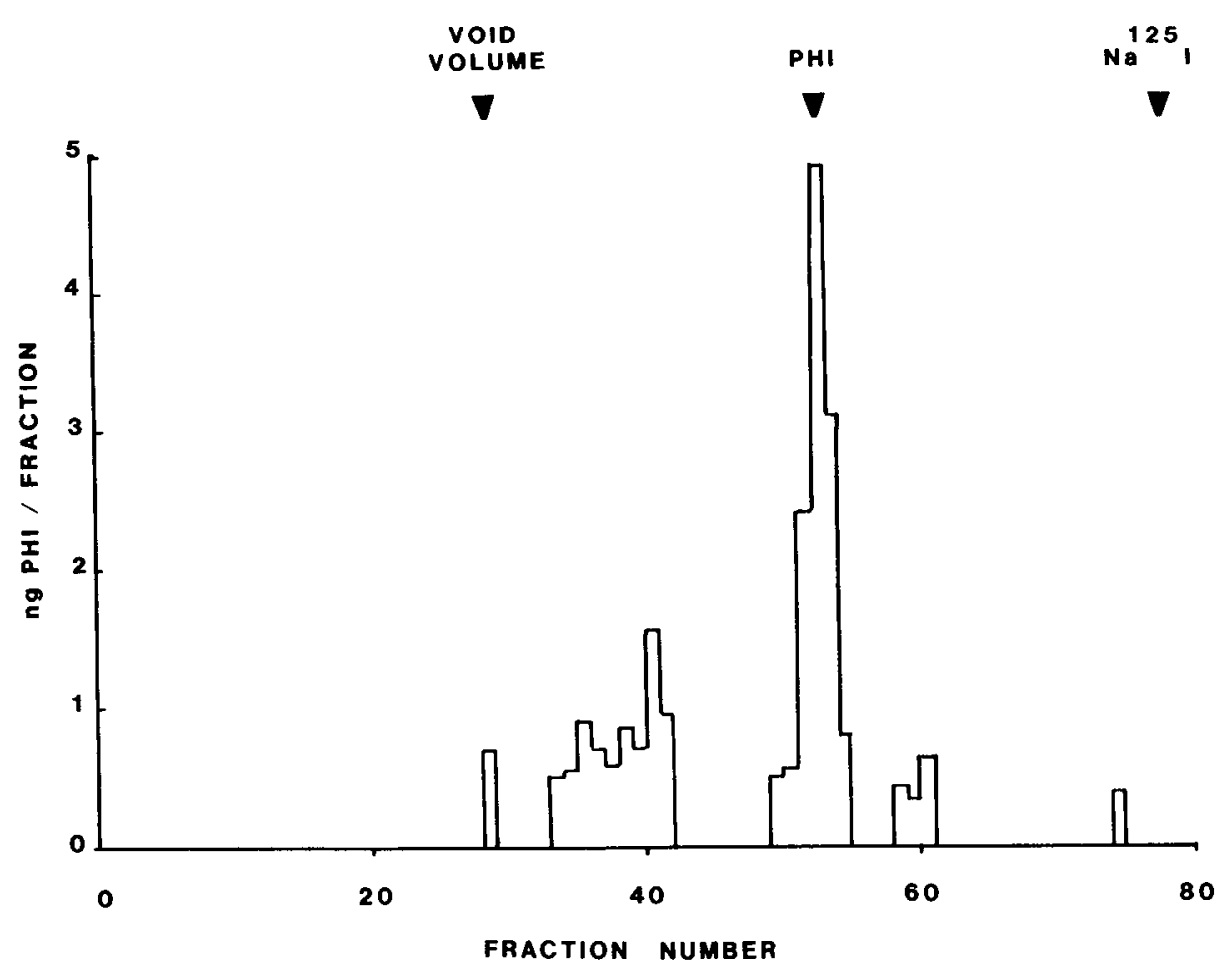

Figure 2. Sephadex G-50 chromatography of a rat brain extract eluted with $1 \%(\mathrm{v} / \mathrm{v})$ acetic acid. Fractions of $2.0 \mathrm{ml}$ were collected. The elution of a rat brain extract and synthetic PHI measured by RIA is compared to the elution of blue dextran (void volume marker) and $\mathrm{Na}^{125} \mathrm{I}$ (included volume marker).

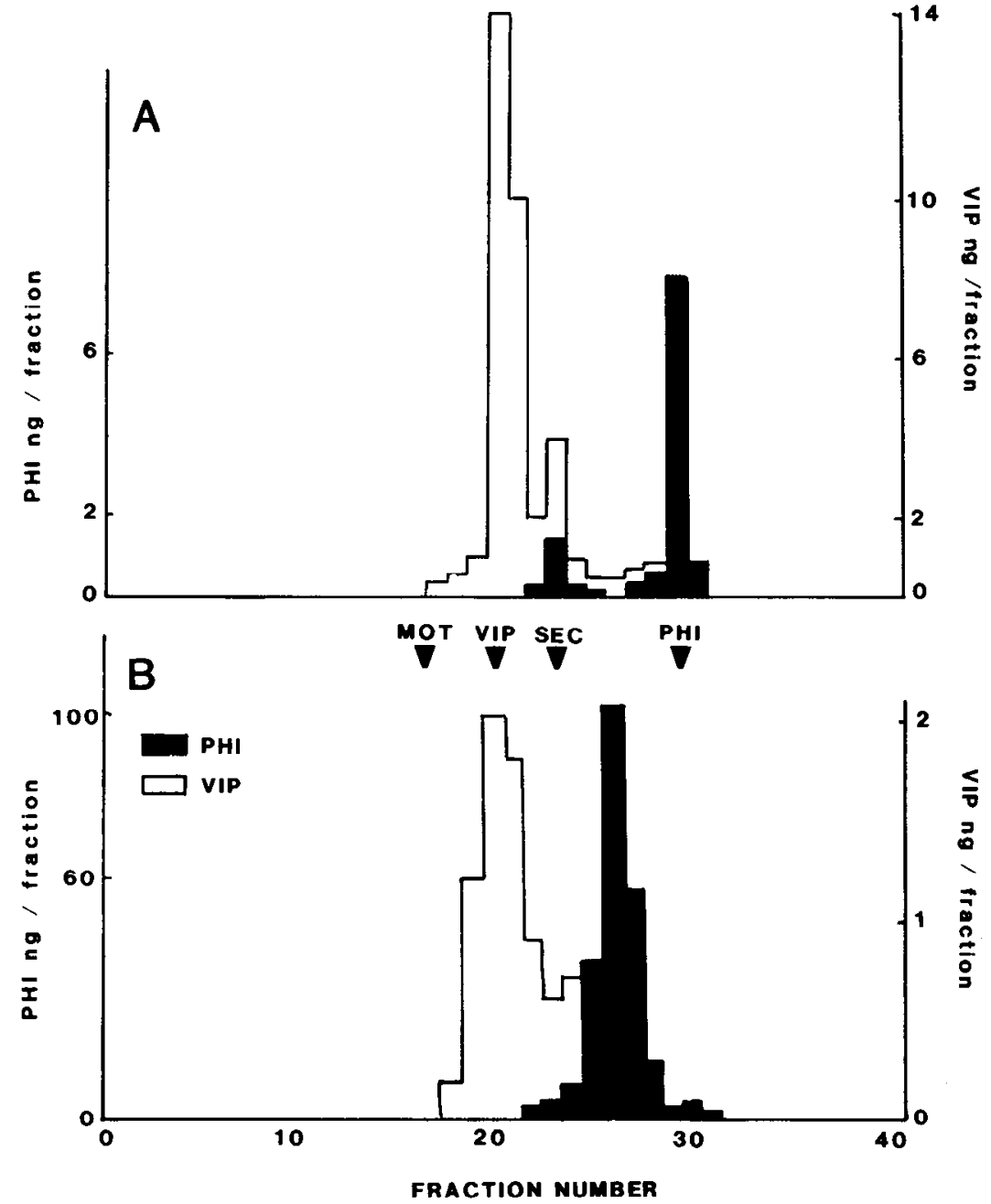

Figure 3. HPLC separation of VIP and PHI peptides of porcine $(A)$ and rat $(B)$ brain extracts in comparison with the elution of synthetic PHI or VIP detected optically or by RIA, or secretin and motilin detected optically. This separation utilized the C18-TEAP system described under "Materials and Methods." 
brain regions is very high, approaching that of cholecystokinin (Beinfeld et al., 1981). Like VIP, PLP is higher in cerebral cortex, hypothalamus, and the limbic system than it is in the thalamus and more caudal poritons of the brain. In most large areas of rat brain measured for PLP and VIP there is no statistical difference between either the concentration or the content of VIP and PLP. In the amygdala and cerebellum, the PLP concentration is higher than that of VIP, whereas in the mesencephalon, olfactory bulb, medulla, and retina the opposite is true.

When the PLP and VIP concentration is compared in micropunches of rat brain, local differences in VIP and PLP concen-

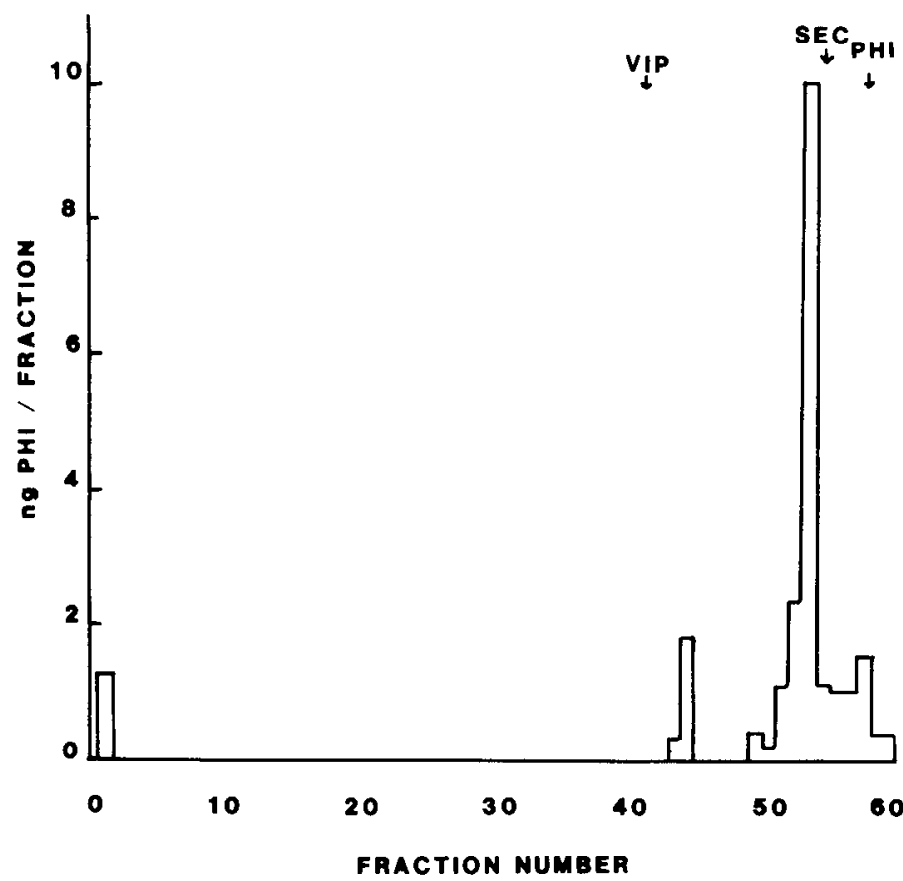

Figure 4. HPLC separation of a rat brain extract on a Waters phenyl column using the TFA system described under "Materials and Methods." Elution of PHI and VIP were detected by RIA, secretin elution was detected optically. tration become more apparent, as is shown in Table III. In more than half of the areas examined, there was a significant difference between the concentration of VIP and PLP. In some areas the difference is quite dramatic: in the suprachiasmatic nucleus, the PLP concentration was $3.6 \pm 0.6$ and VIP was 0.88 \pm 0.05 ; in the posterior hypothalamus the VIP concentration was $0.34 \pm 0.04$ and PLP was undetectable $(<0.09)$. Neither VIP nor PLP is consistently the highest in all areas, although PLP is consistently higher than VIP in cerebral cortex and basal ganglia, whereas VIP is higher than PLP in thalamus and in most areas of the hypothalamus except the suprachiasmatic and periventricular nuclei.

In porcine brain, also, PLP concentrations also closely parallel VIP concentration, and both PLP and VIP are substantially lower in porcine brain than in rat brain (Table IV). That porcine brain has substantially lower VIP levels than does rat brain has been reported previously (Fahrenkrug el al., 1978), although differences in extraction methods between rat and porcine brain used in the present study also account for some of the difference.

\section{Discussion}

Rat and porcine brain contain substantial quantities of a PHI-like peptide (PLP). Based on the Sephadex and HPLC results reported here and on the sequence data of Tatemoto et al. (1983), this porcine brain peptide is identical to PHI. In rat brain, the PLP is similar in molecular weight but either has some alteration in its amino acid sequence or has been posttranslationally modified in a way which has rendered it less polar than synthetic PHI-27. Rat PLP is unlikely to be VIP, secretin, glucagon, GHRH, or PHM-27 since the PHI antiserum detects them so poorly. The sequence of this rat PLP may be quite similar to that of PHI-27 since it has similar trypsin sensitivity and can be detected efficiently with a PHI-27 antiserum. Work is in progress to determine the sequence of rat PLP, to resolve questions about whether it is a PHI-27-related peptide or another new member of the diverse VIP family. It appears that the PHI-27-like sequence is not strongly conserved if porcine and human PLP are known to be different and rat PLP appears to be different than either human or porcine.

The PHI antiserum used in this study displays weak crossreactivity with secretin $(0.8 \%)$ and glucagon $(0.5 \%)$; thus it is

TABLE II

Comparison of the distribution of PHI- and VIP-like immunoreactivity in brains of 200-gm male rats

Data are expressed as picomoles of peptide per milligram of protein or as picomoles of peptide per brain region. Values are mean \pm SEM ( $N$ $=5,6$ ). Statistical comparison between VIP and PHI values was performed with the two-tailed Student's $t$ test.

\begin{tabular}{|c|c|c|c|c|c|}
\hline \multirow[t]{2}{*}{ Brain Region } & $\mathrm{PHI}$ & VIP & \multirow[t]{2}{*}{$\begin{array}{c}\mathrm{PHI} / \mathrm{VIP} \\
\text { Ratio }\end{array}$} & PHI & \multirow[t]{2}{*}{ VIP } \\
\hline & \multicolumn{2}{|c|}{ pmol/mg of protein } & & pmol/region & \\
\hline Cerebral cortex & $1.13 \pm 0.17$ & $1.29 \pm 0.2$ & 0.88 & $71.8 \pm 10.0$ & $82.0 \pm 12.6$ \\
\hline Amygdala & $0.83 \pm 0.08$ & $0.56 \pm 0.05^{\mathrm{a}}$ & 1.48 & $2.9 \pm 0.3$ & $2.0 \pm 0.2$ \\
\hline Hippocampus & $0.46 \pm 0.04$ & $0.43 \pm 0.02$ & 1.07 & $3.6 \pm 0.3$ & $3.4 \pm 0.31$ \\
\hline Anterior hypothalamus & $0.33 \pm 0.03$ & $0.32 \pm 0.03$ & 1.03 & $0.47 \pm 0.03$ & $0.47 \pm 0.05$ \\
\hline Striatum & $0.30 \pm 0.03$ & $0.26 \pm 0.02$ & 1.15 & $3.29 \pm 0.38$ & $2.91 \pm 0.21$ \\
\hline Septum & $0.25 \pm 0.03$ & $0.28 \pm 0.03$ & 0.89 & $0.75 \pm 0.07$ & $0.87 \pm 0.3$ \\
\hline Mesencephalon & $0.25 \pm 0.006$ & $0.28 \pm 0.01^{b}$ & 0.89 & $2.6 \pm 0.26$ & $2.9 \pm 0.23$ \\
\hline Posterior hypothalamus & $0.13 \pm 0.04$ & $0.20 \pm 0.02$ & 0.65 & $0.16 \pm 0.05$ & $0.26 \pm 0.03$ \\
\hline Thalamus & $0.12 \pm 0.025$ & $0.15 \pm 0.02$ & 0.80 & $0.89 \pm 0.16$ & $1.11 \pm 0.17$ \\
\hline Spinal cord & $0.08 \pm 0.006$ & $0.17 \pm 0.04$ & 0.47 & $0.19 \pm 0.04$ & $0.32 \pm 0.04^{a}$ \\
\hline Pons & $0.06 \pm 0.009$ & $0.06 \pm 0.003$ & 1.00 & $0.42 \pm 0.06$ & $0.45 \pm 0.04$ \\
\hline Olfactory bulb & $0.05 \pm 0.009$ & $0.11 \pm 0.012^{b}$ & 0.45 & $0.21 \pm 0.03$ & $0.52 \pm 0.08^{b}$ \\
\hline Cerebellum & $0.05 \pm 0.006$ & $0.008 \pm 0.001^{c}$ & 6.25 & $0.5 \pm 0.04$ & $0.09 \pm 0.01^{c}$ \\
\hline Medulla & $0.04 \pm 0.006$ & $0.14 \pm 0.01^{c}$ & 0.29 & $0.35 \pm 0.06$ & $1.10 \pm 0.06^{c}$ \\
\hline Retina & $0.125 \pm 0.016$ & $0.3 \pm 0.02^{c}$ & 0.42 & $0.08 \pm 0.07$ & $0.20 \pm 0.002^{c}$ \\
\hline
\end{tabular}

${ }^{a} p<0.05$.

${ }^{b} p<0.01$.

${ }^{c} p<0.001$. 
TABLE III

Comparison of the distribution of VIP and PHI immunoreactivity in microdissected region of the rat brain

\begin{tabular}{|c|c|c|c|}
\hline Brain Region & PHI & VIP & $\begin{array}{l}\text { PHI/VIP } \\
\text { Ratio }\end{array}$ \\
\hline & \multicolumn{2}{|c|}{$\mathrm{pmol} / \mathrm{mg}$ of protein } & \\
\hline \multicolumn{4}{|l|}{ Cerebral cortex } \\
\hline Striate cortex & $0.93 \pm 0.09$ & $1.00 \pm 0.06$ & 0.93 \\
\hline Temporal cortex & $1.13 \pm 0.15$ & $0.99 \pm 0.12$ & 1.14 \\
\hline $\begin{array}{l}\text { Frontal, parietal motor } \\
\text { cortex }\end{array}$ & $1.18 \pm 0.11^{a}$ & $0.75 \pm 0.10$ & 1.57 \\
\hline Cingulate cortex & $1.03 \pm 0.04^{b}$ & $0.71 \pm 0.03$ & 1.45 \\
\hline Piriform cortex & $0.93 \pm 0.1$ & $0.61 \pm 0.03$ & 1.52 \\
\hline $\begin{array}{l}\text { Frontal, somatosensory } \\
\text { cortex }\end{array}$ & $0.76 \pm 0.13$ & $0.58 \pm 0.02$ & 1.31 \\
\hline Entorhinal cortex & $0.82 \pm 0.08^{a}$ & $0.58 \pm 0.04$ & 1.41 \\
\hline \multicolumn{4}{|l|}{$\begin{array}{l}\text { Hypothalamic and limbic } \\
\text { system }\end{array}$} \\
\hline $\begin{array}{l}\text { Suprachiasmatic nu- } \\
\text { cleus }\end{array}$ & $3.6 \pm 0.6^{c}$ & $0.88 \pm 0.05$ & 4.09 \\
\hline Medial amygdala & $0.6 \pm 0.05$ & $0.57 \pm 0.04$ & 1.05 \\
\hline Paraventricular nucleus & $0.41 \pm 0.09$ & $0.46 \pm 0.04$ & 0.89 \\
\hline $\begin{array}{l}\text { Nucleus interstitialis } \\
\text { stria terminalis }\end{array}$ & $0.46 \pm 0.14$ & $0.42 \pm 0.07$ & 1.10 \\
\hline Arcuate nucleus & $0.14 \pm 0.03^{c}$ & $0.40 \pm 0.08$ & 0.35 \\
\hline Anterior hypothalamus & $0.25 \pm 0.04$ & $0.37 \pm 0.05$ & 0.68 \\
\hline Dorsomedial nucleus & $0.09 \pm 0.02^{b}$ & $0.36 \pm 0.05$ & 0.25 \\
\hline Posterior hypothalamus & $\mathrm{ND},<0.09^{d}$ & $0.34 \pm 0.04$ & \\
\hline Periventricular nucleus & $1.47 \pm 0.41^{c}$ & $0.32 \pm 0.03$ & 4.59 \\
\hline Medial preoptic nucleus & $0.07 \pm 0.00^{b}$ & $0.30 \pm 0.02$ & 0.23 \\
\hline Lateral septum & $0.24 \pm 0.10$ & $0.27 \pm 0.04$ & 0.89 \\
\hline Median eminence & $\mathrm{ND},<0.125$ & $0.26 \pm 0.06$ & \\
\hline Ventromedial nucleus & $\mathrm{ND},<0.05$ & $0.23 \pm 0.02$ & \\
\hline Medial septum & $0.13 \pm 0.02^{c}$ & $0.21 \pm 0.02$ & 0.62 \\
\hline Subiculum & $0.18 \pm 0.02^{c}$ & $0.18 \pm 0.05$ & 1.00 \\
\hline Supraoptic nucleus & $0.08 \pm 0.02^{\mathrm{c}}$ & $0.17 \pm 0.02$ & 0.47 \\
\hline Hippocampus & $0.18 \pm 0.02$ & $0.17 \pm 0.02$ & 1.06 \\
\hline Dentate gyrus & $0.24 \pm 0.08$ & $0.14 \pm 0.02$ & 1.71 \\
\hline Preoptic lateral nucleus & $0.08 \pm 0.02$ & $0.12 \pm 0.01$ & 0.67 \\
\hline Lateral amygdala & $0.06 \pm 0.002^{b}$ & $0.08 \pm 0.001$ & 0.75 \\
\hline Mammillary bodies & $\mathrm{ND},<0.02$ & $0.06 \pm 0.001$ & \\
\hline Nucleus tr. diag. & $0.06 \pm 0.001^{b}$ & $0.19 \pm 0.003$ & 0.32 \\
\hline \multicolumn{4}{|l|}{ Basal ganglia } \\
\hline Nucleus accumbens & $0.65 \pm 0.05^{e}$ & $0.42 \pm 0.02$ & 1.55 \\
\hline Caudate-putamen & $0.07 \pm 0.006^{c}$ & $0.04 \pm 0.006$ & 1.75 \\
\hline Globus pallidus & $0.15 \pm 0.04$ & $0.11 \pm 0.04$ & 1.36 \\
\hline \multicolumn{4}{|l|}{ Thalamus } \\
\hline $\begin{array}{l}\text { Periventricular nucleus } \\
\text { thal. }\end{array}$ & $0.18 \pm 0.03^{a}$ & $0.32 \pm 0.04$ & 0.56 \\
\hline Habenula & $0.03 \pm 0.006^{b}$ & $0.11 \pm 0.01$ & 0.27 \\
\hline \multicolumn{4}{|l|}{ Brainstem } \\
\hline Interpeduncular nucleus & $0.15 \pm 0.02^{a}$ & $0.22 \pm 0.02$ & 0.68 \\
\hline Periaqueductal gray & $0.25 \pm 0.02$ & $0.21 \pm 0.002$ & 1.19 \\
\hline $\begin{array}{l}\text { Medial geniculate nu- } \\
\text { cleus }\end{array}$ & $0.26 \pm 0.03$ & $0.21 \pm 0.002$ & 1.24 \\
\hline Dorsal raphe nucleus & $0.23 \pm 0.06$ & $0.21 \pm 0.002$ & 1.10 \\
\hline Superior colliculus & $0.47 \pm 0.04^{b}$ & $0.08 \pm 0.006$ & 5.88 \\
\hline Inferior colliculus & $0.12 \pm 0.03$ & $0.06 \pm 0.001$ & 2.00 \\
\hline $\begin{array}{l}\text { Substantia nigra pars } \\
\text { reticulata }\end{array}$ & $0.03 \pm 0.01$ & $0.04 \pm 0.001$ & 0.75 \\
\hline $\begin{array}{l}{ }^{a} p<0.05 . \\
{ }^{b} p<0.001 . \\
{ }^{c} p<0.02 . \\
{ }^{d} \mathrm{ND}, \text { nondetectable. T } \\
\text { ample size and detection }\end{array}$ & 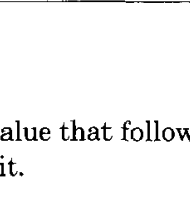 & 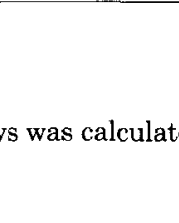 & 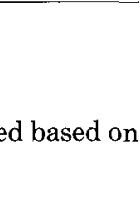 \\
\hline
\end{tabular}

conceivable that a small percentage of what is detected in the PHI RIA consists of cross-reacting secretin peptides known to be present in rat and porcine brain (O'Donohue et al., 1981). However, the levels of secretin are generally much lower than the levels of PHI, and areas which are high in secretin (e.g., thalamus) are low in PHI. Likewise the cerebral cortex, which is high in PHI, has the lowest secretin content of rat brain regions. Even in hypothalamus, where secretin is high, with $0.8 \%$ cross-reactivity between PHI-27 and secretin, only 16 of $2000 \mathrm{pg}$ measured for PHI would be contributed by secretin. Glucagon can be expected to contribute even less to the tissue PHI levels measured because the cross-reactivity is lower than for secretin and the glucagon levels in the brain are even lower than those of secretin (Tager et al., 1980).

The possibility that we are detecting as yet unknown members of the VIP-PHI-secretin-glucagon peptide family with the PHI RIA cannot, of course, be excluded. However, the observation that the rat and porcine brain $\mathrm{PHI}$-like material elutes as a single major peak on three different HPLC systems makes this possibility unlikely. Minor peaks of PHI-like and VIP-like immunoreactivity were observed in porcine brain which may represent new members of this peptide family. The possibility that one or more of the minor high molecular weight peaks eluting from the Sephadex column is in fact a non-PHI, immunologically related peptide cannot be excluded.

The distribution of VIP and PHI is positively correlated in rat and porcine brain, even though rat brain has at least 5 times more VIP than porcine brain. In older $(400 \mathrm{gm})$ rats where VIP levels are reduced (Beinfeld et al., 1983) relative to 200 -gm rats (as in Table II), the PHI levels are also reduced proportionately (data not shown). In some brain nuclei (the suprachiasmatic and periventricular nuclei of the hypothalamus) $\mathrm{PHI}$ is 3 to 5 times more abundant than VIP, whereas in other areas (posterior hypothalamus or ventromedial nucleus of the hypothalamus) VIP is 3 to 4 times more abundant than PHI. Given the possibility that PHI and VIP occur in the same neurons and that they may arise from the same precursor, this difference in concentration could reflect local differential regulation of gene products, as in the case of the pro-opiomelanocortin precursor (Mains and Eipper, 1981), or differential regulation of mRNA splicing and processing or differential metabolism of the processed peptides. Another possible cxplanation is that addition, as yet undiscovered, members of the VIP family of peptides exist which cross-react differentially with the VIP and PHI RIA in different brain regions, causing an apparent nonuniform distribution of VIP and PHI.

Whether PHI and VIP are co-localized in the same neurons is still under investigation, and there have been positive (Christofides et al. 1982a, b) and negative (Hokfelt et al., 1982) reports in specific brain areas. Hokfelt et al. (1982) report dense PHI fiber staining in the median eminence whereas VIP stains weakly there; also, PHI but not VIP antiserum stains cells in the paraventricular nucleus of the hypothalamus. We report here that, by RIA, the median eminence has measurable VIP levels $(0.85+0.21 \mathrm{ng} / \mathrm{mg}$ of protein), whereas $\mathrm{PHI}$ is below the detection limit $(<0.25)$. The VIP and PHI levels in the paraventricular nucleus are similar $(\sim 1.5)$. The reasons for this discrepancy are not apparent, but since the PHI RIA is markedly less sensitive than the VIP RIA, the immunocytochemical technique of Hokfelt et al. (1982) may be more sensitive than the VIP RIA and can more easily detect PHI in the median eminence. The immunocytochemical techniques used by Hokfelt et al. (1982) may also have lacked the sensitivity to detect VIP and PHI in all brain regions. Differences in detectability between RIA and immunocytochemistry have been frequently observed in the past (Beinfeld and Palkovits, 1982, for example). 
TABLE IV

Comparison of VIP and PHI immunoreactivity in porcine brain regions

Data are expressed as picomoles of peptide per gram of tissue or as picomoles of peptide per brain region. Values are mean $\pm \mathrm{SEM}(N=3$ to 5). Statistical comparison was performed with a two-tailed Student's $t$ test.

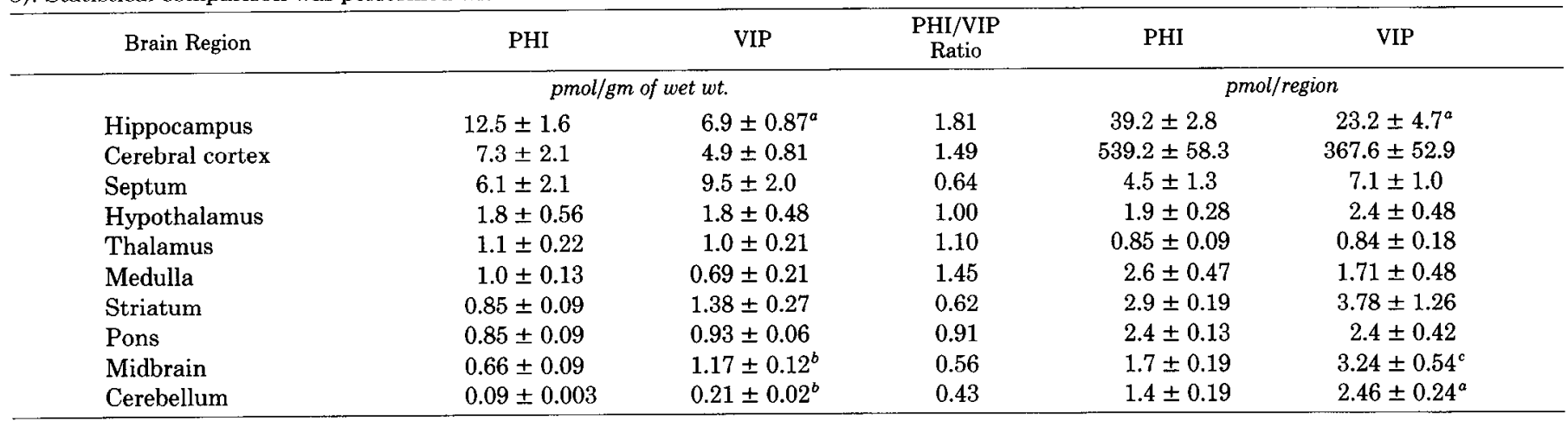

\footnotetext{
${ }^{a} p<0.05$

${ }^{b} p<0.01$.

${ }^{c} p<0.02$.
}

Preliminary binding data indicate that PHI-27 can potently inhibit the binding of ${ }^{125} \mathrm{I}$-labeled VIP to rat brain membranes, with an affinity in the nanomolar range. Whether rat brain PLP can also displace labeled VIP from its binding sites has not been determined but is under investigation. The ability of PHI-27 to competitively inhibit VIP binding has been reported in a number of other tissues (Bataille et al., 1980; Jensen et al., 1982; Robberecht et al., 1982), which suggests that PHI could be an agonist or antagonist for VIP receptors. That PHI-27 has VIP- and secretin like actions in carp retina (Watling and Dowling, 1983) and in a neuroblastoma cell line (Roth et al., 1984 ) is suggestive of agonist rather than antagonist activity. These observations are suggestive of a possible role of PLPs as an endogenous VIP-like agonist or antagonist in the central nervous system.

\section{References}

Bataille, D., C. Gespach, M. Laburthe, B. Amiranoff, K. Tatemoto, N. Vauclin, V. Mutt, and G. Rosselin (1980) Porcine peptide having Nterminal histidine and C-terminal isoleucine amide (PHI). FEBS Lett. 114: 240-242.

Beinfeld, M. C., and M. Palkovits (1982) Distribution of cholecystokinin (CCK) in the rat lower brain stem nuclei. Brain Res. 238: 260265.

Beinfeld, M. C., D. K. Meyer, R. L. Eskay, R. T. Jensen, and M. J. Brownstein (1981) The distribution of cholecystokinin immunoreactivity in the central nervous system of the rat as determined by radioimmunoassay. Brain Res. 212: 51-57.

Beinfeld, M. D., D. M. Korchak, and G. Nilaver (1983) The development of motilin, choleystokinin, and vasoactive intestinal peptide immunoreactivity in the forebrain and hindbrain of the rat, as determined by radioimmunoassay. Dev. Brain Res. 10: 146-150.

Christofides, N. D., Y. Yiangou, M. A. Blank, K. 'Tatemoto, J. M. Polak, and S. R. Bloom (1982a) Are peptide histidine isoleucine and vasoactive intestinal peptide co-synthesized in the same pro-hormone? Lancet 2: 1398 .

Christofides, N. D., Y. Yiangou, P. McGregor, E. Aarons, P. Woodhams, K. Tatemoto, and S. R. Bloom (1982h) Distribution of PHI in the rat brain. Biomed. Res. 3: 573-574.

Christofides, N. D., Y. Yiangou, E. Aarons, G. Ferri, K. Tatemoto, J. Polak, and S. R. Bloom (1983) Radioimmunoassay and intramural distribution of PHI-IR in human intestine. Dig. Dis. Sci. 28: 507512.

Christophe, J. P., T. P. Conlon, and J. D. Gardner (1976) Interaction of porcine vasoactive intestinal peptide with dispersed pancreatic acinar cells from the guinea pig. J. Biol. Chem. 251: 4629-4634.
Dimaline, R., J. R. Reeve, D. Hanke, J. Shively, J. H. Walsh, and G. $J$. Dockray (1983) Amino acid sequence of rat VIP and partial sequence of a VIP variant. Regul. Pept. 6: 298.

Eiden, L. E., G. Nilaver, and M. Palkovits (1982) Distribution of vasoactive intestinal peptide (VIP) in the rat brain stem nuclei. Brain Res. 231: 472-477.

Fahrenkrug, J., and O. B. Schaffalitzky de Muckadell (1978) Distribution of vasoactive intestinal polypeptide (VIP) in the porcine central nervous system. J. Neurochem. 31: 1445-1451.

Hokfelt, T., J. Fahrenkrug, K. Tatemoto, V. Mutt, and S. Werner (1982) PHI, a VIP-like peptide, is present in the rat medial eminence. Acta Physiol. Scand. 116: 469-471.

Itoh, N., K. Obata, N. Yanaihara, and H. Okamoto (1983) Human preprovasoactive intestinal polypeptide contains a novel PHI-27-like peptide, PHM-27. Nature 304: 547-549.

Jensen, R. T., K. Tatemoto, V. Mutt, G. Lemp, and J. Gardner (1982) Actions of a newly isolated intestinal peptide, $\mathrm{PHI}$, on pancreatic acini. Am. J. Physiol. 241: G498-G502

Lowry, O. H., N. J. Rosebrough, A. L. Farr, and R. J. Randall (1951) Protein measurement with the Folin phenol reagent. J. Biol. Chem. 193: 265-275.

Mains, R. E., and B. A. Eipper (1981) Differences in the post-translational processing of $\beta$-endorphin in rat anterior and intermediate pituitary. J. Biol. Chem. 256: 5683-5688.

O'Donohue, T. L., C. G. Charlton, R. L. Miller, G. Boden, and D. M. Jacobowitz (1981) Identification, characterization, and distribution of secretin immunoreactivity in rat and pig brain. Proc. Natl. Acad. Sci. U. S. A. 78: 5221-5224.

Palkovits, M. (1973) Isolated removal of hypothalamic or other brain nuclei of the rat. Brain Res. 59: 449-459.

Robberecht, P., K. Tatemoto, P. Chatelain, M. Waelbroeck, M. Delhaye, G. Taton, P. DeNeff, J. C. Camus, D. Heuse, and J. Christophe (1982) Effects of PHI on vasoactive intestinal peptide receptors and adenylate cyclase activity in lung membranes. A comparison in man, rat, mouse, and guinea pig. Regul. Pept. 4: 241-250.

Rodbard, D., and P. J. Munson (1980) RIA data processing. In Manual of Clinical Immunology, Ed. 2, N. R. Rose and H. Friedman, eds., pp. 343-349, American Society of Microbiology, Washington, D.C.

Roth, B. L., M. C. Beinfeld, and A. C. Howlett (1984) Secretin receptors on neuroblastoma cell membranes: Characterization of ${ }^{125}$ I-labeled secretin binding and association with adenylate cyclase. J. Neurochem. 42: 1145-1152.

Said, S. I., and V. Mutt (1970) Polypeptide with broad biological activity: Isolation from small intestine. Science 169: 1217-1218.

Tager, H., M. Hohenboken, J. Markese, and R. J. Dinerstein (1980) Identification and localization of glucagon-related peptides in rat brain. Proc. Natl. Acad. Sci. U. S. A. 77: 6229-6233.

Tatemoto, K., and V. Mutt (1981) Isolation and characterization of the intestinal peptide porcine PHI (PHI-27), a new member of the 
glucagon-secretin family. Proc. Natl. Acad. Sci. U. S. A. 78: 66036607.

Tatemoto, K., M. Carlquist, T. McDonald, and V. Mutt (1983) Isolation of a brain peptide identical to the intestinal PHI (Peptide HI). FEBS Lett. 153: 248-252.

Watling, K. J., and J. E. Dowling (1983) Effects of vasoactive intestinal peptide and other peptides on cyclic AMP accumulation in intact pieces and isolated horizontal cells of the teleost retina. J. Neurochem. 41: 1205-1213.

Werner, S., A. L. Hulting, T. Hokfelt, P. Eneroth, K. Tatemoto, V. Mutt, L. Maroder, and E. Wunsch (1983) Effect of the peptide PHI27 on prolactin release in vitro. Neuroendocrinology $37: 476-478$. 